J. Clin. Chom. Clin. Biochom.

Vol. 15, 1977, pp. 575-577

\title{
Cross Reactivity of Rabbit Antibodies against Purified Animal Enzymes
}

\section{Comparison of Enzymes of Human and Animal Origin, II}

By W. Gruber, Barbara Zapf, K.-H. Schrappe and R. Linke

Boeluringer Mannheim GmbH, Biochemica Werk Tutzing

(Received February 7/May 31, 1977)

Summary: Enzyme preparations used for quality control of enzyme activity determinations in clinical chemistry should be very similar to human enzymes. Antibodies against c. g. porcine enzymes show cross reactivity with the corresponding human enzymes, indicating partial identity of the enzyme proteins. As the enzyme-antibody precipitates retain catalytic activity the similarity between the enzyme proteins is not limited to the catalytic sites.

\section{Kreuzreaktionen von Kaninchen-Antikörpern gegen gereinigte tierische Enzyme}

\section{Vergleich humaner und tierischer Enzyme, II. Mitteilung}

Zusammenfassung: Enzympräparate für den Einsatz in Qualitätskontrollproben für die klinische Chemie müssen den entsprechenden Humanenzymen möglichst ähnlich sein. Antikörper gegen Enzyme aus Schweine-Organen zeigen Kreuzreaktionen mit den Enzymen humanen Ursprungs. Hierdurch wird teilweise Identität der Enzymproteine angezeigt. Die entstehenden Enzym-Antikörper-Präzipitate zeigen noch enzymatische Aktivität, die zu ihrem Nachweis verwendet werden kann. Die Identität der Proteine beschränkt sich also nicht auf das aktive Zentrum.

\section{Introduction}

Enzymes from animal sources are frequently used for quality control of enzyme activity determinations in clinical chemistry. For this purpose they should be very similar to human enzymes. In the preceding paper it was shown that preparations of enzymes with the same functions from human and porcine organs, purified in exactly the same way, have very similar pH-optima and apparent Michaelis constants for their substrates. This again indicates the similarity of the catalytic sites of corresponding enzymes from different animals. To check the relation of the protein structure of these enzymes further we performed some immuno-chemical studies on our purified enzymes.

\section{Materials and Methods}

All enzymes, coenzymes and most substrates used were products of Boehringer Mannheim GmbH. Buffers and other reagents were purchased from E. Merck, Darmstadt.

The enzymes studied were purified as stated before (1). Each preparation was used for the immunization of 3 rabbits. Immunization was performed by injection of $0.5 \mathrm{mg}$ protein (excoption: creatine kinasc: $1 \mathrm{mg}$ protein) dissolved in $0.25 \mathrm{ml}$ sodium chloride solution $(9 \mathrm{~g} / \mathrm{l})+0.25 \mathrm{ml}$ complote Freund's adjuvant into the foot-pads of each rabbit, following by i. m., s. c. and i. v. booster injections with the above solution 1, 2,
4 and 6 weeks later. Blood was taken in the 8 th weck and serum collected after coagulation on standing.

The cross rcactivity of the antibodics with the enzymes from different sources was checked by the double diffusion technique of Ouchterlony. The center hole of agar plates was filled with antibody, surrounding holes alternating with human and animal cnzymes in descending dilutions. After $48 \mathrm{~h}$ diffusion, nonprecipitated proteins were washed out by keeping the plates twice for 2 hours in physiological saline solution.

Protein precipitates in the agar slides were specifically stained with Coomassie Brilliant Bluc R-250, using the technique described in 1. c. (2).

All antibody-bound enzyme precipitates were also stained by enzyme-specific reactions, adapting colorimetric assay principles, some of which are already used in enzyme electrophoresis. With some enzyme precipitates the best results were obtained by covering the Ouchterlony-plate without drying with dilute agar-gel $(4 \mathrm{~g} / \mathrm{l})$ containing the ingredients for enzymatic staining. With other enzymes we prefered drying the Ouchterlony-plate in a desiccator with calcium chloride and incubating tho dried plate in an ingredient solution.

The following conditions and concentrations were used for the different enzymes:

\section{Creatine Kinase $(3,4)$}

(ATP: creatine N phosphotransferase, EC 2.7.3.2)

triethanolamine pH 7.5, magnesium chloride

glucose

ADP

AMP

$0.1 \mathrm{~mol} / 1$

$1 \mathrm{mmol} / 1$

$7.3 \mathrm{mmol} / 1$

$1 \mathrm{mmol} / \mathrm{l}$

$10 \mathrm{mmol} / \mathrm{l}$ 
NADP

creatine phosphate

phenazoniummethosulphate

INT (2(p-Jodphenyl)-3-(p-nitrophenyl)-5-

phenyltetrazolium chloride)

hexokinase

glucose-6-phosphate-dehydrogenase

agar

$\begin{array}{rl} & 0.4 \mathrm{mmol} / \\ 2.2 \mathrm{mmol} / 1 \\ 0.5 \mathrm{~g} / \mathrm{l} \\ 2 & \mathrm{~g} / 1 \\ & \\ 1000 & \mathrm{U} / 1 \\ 1000 & \mathrm{U} / 1 \\ 4 & \mathrm{~g} / 1\end{array}$

Incubate double layer $1 \mathrm{~h}$ at $37^{\circ} \mathrm{C}$; remove staining layer by washing. Enzyme-specific stained precipitate is fixed with acetic acid $(2 \mathrm{~g} / \mathrm{l})$ for $10 \mathrm{~min}$. Plates are washed with water (30 min) and dried. They can be stored for many months.

\section{Alanine Aminotransferase (5)}

(L-Alanine: 2-oxoglutarate aminotransferase, EC 2.6.1.2)

phosphate buffer $\mathrm{pH} 7.4$,

2-oxoglutarate

$D, L$-alanine

NAD

phenazoniummethosulphate

INT (2(p-Jodphenyl)-3-(p-nitrophenyl)-5-

phenyltetrazolium chloride)

glutamate dehydrogenase

agar

$$
\begin{array}{cc}
0.1 & \mathrm{~mol} / \mathrm{l} \\
1 & \mathrm{mmol} / \mathrm{l} \\
100 & \mathrm{mmol} / 1 \\
4 & \mathrm{mmol} / \mathrm{l} \\
0.3 \mathrm{~g} / \mathrm{l} \\
1 & \mathrm{~g} / \mathrm{l} \\
& \\
0.4 \mathrm{~g} / \mathrm{l}= \\
40 & \mathrm{kU} / 1 \\
4 & \mathrm{~g} / \mathrm{l}
\end{array}
$$

Technique: Same as described for creatine kinase.

Aspartate Aminotransferase (6)

(L-Aspartate: 2-oxoglutarate aminotransferase, EC 2.6.1.1)

phosphate buffer $\mathrm{pH} 7.4$,

2-oxoglutaric acid

$L$-aspartic acid

EDTA

Fast Garnet GBC

$0.1 \mathrm{~mol} / 1$

$5 \mathrm{mmol} / 1$

$20 \mathrm{mmol} / 1$

$1 \mathrm{~g} / 1$

$4 \mathrm{~g} / 1$

Technique: Dried agar plate is incubated with a substrate-color solution for $20-30 \mathrm{~min}$ at $37^{\circ} \mathrm{C}$.

$\gamma$-Glutamyl Transferase (7)

(( $\gamma$-glutamyl)-peptide: amino-acid $\gamma$-glutamyl-transferase, EC 2.3.2.2)

phosphate buffer $\mathrm{pH} 6.7$, $\gamma$-glutamyl- $\beta$-naphthylamide glycyl-glycine

Fast Garnet GBC

$40 \mathrm{mmol} / 1$

$2 \mathrm{mmol} / \mathrm{l}$

$25 \mathrm{mmol} / \mathrm{l}$

$0.5 \mathrm{~g} / \mathrm{l}$

Technique: As described for aspartate aminotransferase.
Lactate Dehydrogenase (8)

(L-lactate: NAD oxidoreductase, EC 1.1.1.27)

Tris buffer $\mathrm{pH} 8.4$,

$L$-lactate

NAD

MTT (3(4,5-Dimethylthiazolyl-2)-2,5-

diphenyltetrazolium bromide)

phenazoniummethosulphate

$$
\begin{aligned}
& 0.1 \mathrm{~mol} / 1 \\
& 60 \mathrm{mmol} / 1 \\
& 5 \mathrm{mmol} / \mathrm{l} \\
& 1 \mathrm{~g} / \mathrm{l} \\
& 0.2 \mathrm{~g} / 1
\end{aligned}
$$

Technique: As described for $\gamma$-glutamyl transferase.

\section{Glutamate Dehydrogenase}

( $L$-glutamate: NAD(P) oxidoreductáse, EC 1.4.1.3)

Same technique and solution as described for lactate dehydrogenase, $L$-glutamate $(60 \mathrm{mmol} / \mathrm{l})$ instead of $L$-lactate.

\section{Malate Dehydrogenase}

( $L$-malate: NAD oxidoreductase, EC 1.1.1.37)

Technique and solution as described for lactate dehydrogenase. $L$-malate $(60 \mathrm{mmol} / \mathrm{l})$ instead of $L$-lactate.

\section{Results and Discussion}

All the enzyme preparations used gave rise to antibodies in all the rabbits injected. The antibody titers for each enzyme differed over a range of 100 -fold between the three rabbits used. The specificity of the antibodies within any group was the same. Antibodies from each of three rabbits showed similar precipitation patterns in the Ouchterlony double diffusion technique.

With the protein-specific Coomassie staining nearly all enzyme preparations gave single precipitation lines (some gave a very weak second line), indicating the high purity of the enzymes used for immunization. All precipitates could be stained by reactions that exploited the specific catalytic activity of the appropriate enzyme. Therefore all our enzyme-antibody precipitates had residual enzyme activity. All enzyme-specific stainings showed exactly the same precipitation lines as the coomassie protein stainings. Typical examples are shown in the photographs below for the $\mathrm{H}_{4}$-isoenzyme of

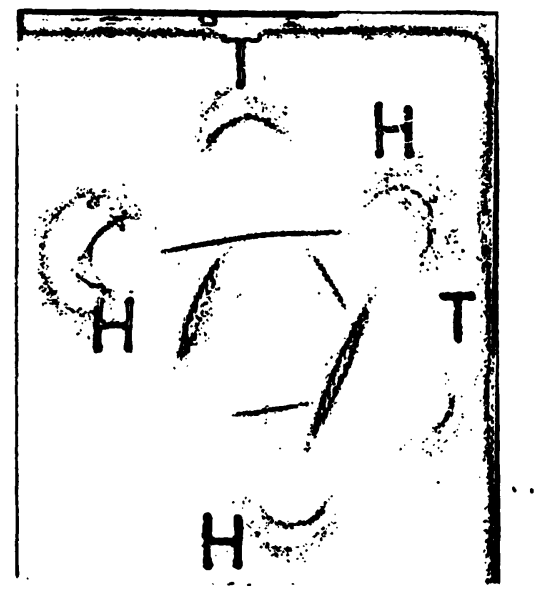

Fig. 1 a. $\mathrm{M}_{4}$-isoenzyme of lactate dehydrogenase Coomassie staining

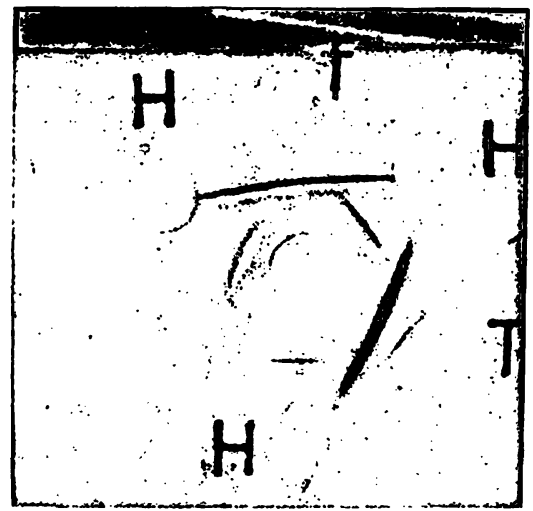

Fig. 1 b. $M_{4}$-isoenzyme of lactate dehydrogenase Tetrazolium salt staining

Center well: Antibody raised against porcine $\mathrm{M}_{4}$-isoenzyme of lactate dehydrogenase

Outer wells T: Porcine $\mathrm{M}_{4}$-isoenzyme of lactate dehydrogenase

Outer wells $\mathrm{H}$ : Human $\mathrm{M}_{4}$-isoenzyme of lactate dehydrogenase 


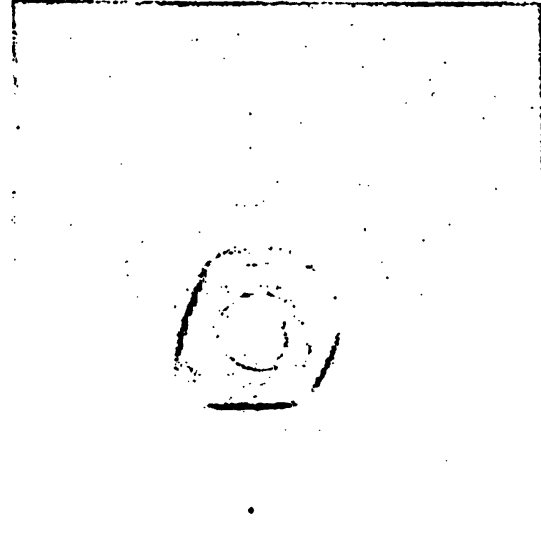

Fig. 2a. $\mathrm{H}_{4}$-isoenzyme of lactate dehydrogenase Coomassie staining

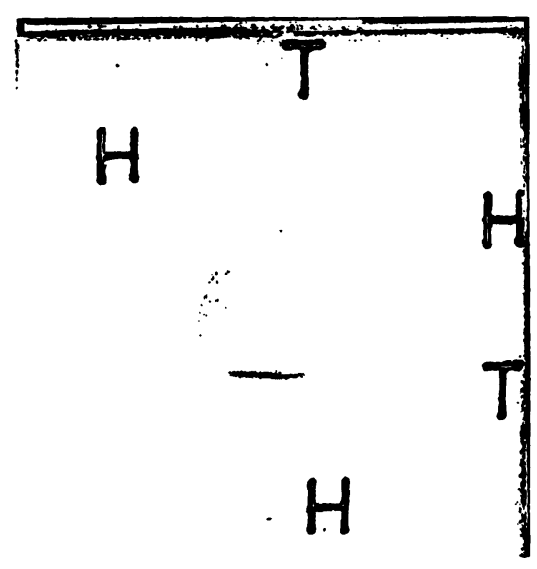

Fig. 2b. $\mathrm{H}_{4}$-isoenzyme of lactate dehydrogenase Tetrazolium salt staining

Center well: Antibody raised against porcine $\mathrm{H}_{4}$-isoenzyme of lactate dehydrogenase

Outer wells T: Porcine $\mathrm{H}_{4}$-isoenzyme of lactate dehydrogenase

Outer wells $\mathrm{H}$ : Human $\mathrm{H}_{4}$-isoenzyme of lactate dehydrogenase

lactate dehydrogenase and the $\mathrm{M}_{4}$-isoenzyme of lactate dehydrogenase from human $(\mathrm{H})$ and porcine $(\mathrm{T})$ organs at different concentrations, using antibodies against the porcine enzymes. Figures $1 \mathrm{a}$ and $2 \mathrm{a}$ show protein-specific Coomassie staining of the precipitation lines, whereas figure $1 \mathrm{~b}$ and figure $2 \mathrm{~b}$ show enzyme-specific staining. As can be seen there is total identity of determinants of porcine and human $\mathrm{H}_{4}$-isoenzyme of lactate dehydrogenase, whereas the muscle enzymes are partially identical only.

The results of our studies are summarized in table 1; total identity of determinants was only seen with $\mathrm{H}_{4}$ isoenzyme of lactate dehydrogenase. All other enzymes studied showed partial identity in antibody binding, even with enzyme-specific staining. This is indicative of similarities in the protein structure, in addition to the similarities at the catalytic sites, which were shown e.g. in our preceding paper (9).

\section{References}

1. Gruber, W., Möllering, H. \& Perras, L. (1977), this J. 15, 565-573.

2. Axelsen, N. H., Kröll, J. \& Weeke, B. (1973), A Manual of Quantitative Immunoelectrophoresis, page 26, Universitetsforlaget Oslo, Norway.

3. Van der Veen, K. J. \& Willebrands, A. F. (1966), Clin. Chim. Acta 13, 312-316.

4. Caroll, J., Smith, N. \& Babson, A. L. (1970), Biochem. Med. 4, 171.

5. Lippi, U. \& Guidi, G. (1970), Clin. Chim. Acta 28, 431-437.

6. Babson, A. L., Shapiro, P. O., Williams, P. A. R. \& Phillips, G. E. (1962), Clin. Chim. Acta 7, 199-205.

7. Bruch, J. E., Domecq, R. \& Findor, J. (1973), Klin. Wochenschr. $51,272-274$.

8. Thum, W., Wahlefeld, A. W., Näher, G., Gruber, W., Möllering, H., Weimann, G. \& Bergmeyer, H. U. DPS 2061984.

9. Grüber, W., Möllering, H. \& Perras, L. (1977), this J. 15, $565-573$.

10. Rajewisky, K. (1966), Immunochemistry 3, 487-489.

11. Burd, J. F. (1973), Clin. Chim. Acta 46, 205-215.
Tab. 1. Cross reactivity of antibodies against human and porcine enzymes with both antigens as studied with the Ouchter. lony double diffusion technique.

\begin{tabular}{lll}
\hline Enzyme & $\begin{array}{l}\text { Total } \\
\text { identity }\end{array}$ & $\begin{array}{l}\text { Partial } \\
\text { identity }\end{array}$ \\
\hline creatine kinase & & $\mathrm{X}$ \\
alanine aminotransferase & $\mathrm{X}$ \\
aspartate aminotransferase & $\mathrm{X}$ \\
malate dehydrogenase & & $\mathrm{X}$ \\
$\mathbf{M}_{4}$-isoenzyme of lactate dehydrogenase & & $\mathrm{X}$ \\
$\mathbf{H}_{\mathbf{4}}$-isoenzyme of lactate dehydrogenase & $\mathrm{X}$ & $\mathrm{X}$ \\
glutamate dehydrogenase & & $\mathrm{X}$ \\
r-glutamyl transferase & & $\mathrm{X}$ \\
\hline
\end{tabular}

Partial similarities in the protein structure of enzymes with the same functions from different animals are already known, e. g. as shown by amino acid sequencing etc. (for summary see 1. c. 1).

Some comparitive immunochemical studies on enzymes from different sources have also been published $(10,11)$, including a few reports on some human enzymes(12-19).

12. Pfleiderer, G., Lang, H., Hennrich, N. \& Orth, H. D., DOS 2258822 .

13. Plagemann, P. G. W., Gregory, K. \& Wroblewski, F. (1960), J. Biol. Chem. 235, 2288-2293.

14. Kaplan, N. O., Ciotti, M. M. \& Hamolsky, M. (1960), Science 131, 392.

15. Kaplän, N. O. \& White, S. (1963), Ann. N. Y. Acad. Sci. 103,835

16. Wilson, A. C., Kaplan, N. O., Levine, L., Pesce, A., Reichlin, M. \& Allison, W. S. (1964), Fed. Amer. Soc. Exp. Biol. 23, 1258-1266.

17. Rajewsky, K., Avrameas, S., Grabar, P., Pfleiderer, G. \& Wachsmuth, E. D. (1964), Biochim. Biophys. Acta 92, 248-259.

18. Miller, S. P., Awashi, Y. C. \& Srivastava, S. K. (1976), J. Biol. Chem. 251, 2271-2278.

19. Lehmann, F. G. \& Pfleiderer, G. (1969), Hoppe Seyler's Z. Physiol. Chem. 350, 609-616.

Dr. W. Gruber Boehringer Mannheim GmbH Biochemica Werk Tutzing P. O. Box 120 D-8132 Tutzing 
